Research paper

\title{
Oral Bioavailability Enhancement of Efavirenz using Piperine coadministration in Experimental Rabbits
}

\author{
Mohammad Asif ${ }^{1, *}$, Hardik P Patel ${ }^{2}$ and Rakesh K Patel $^{2}$ \\ ${ }^{1}$ Department of Pharmacognosy, Lachoo Memorial College of Science \& Technology, Jodhpur, Rajasthan, 342001, India \\ ${ }^{2}$ Department of Pharmacognosy, S.K. Patel College of Pharmaceutical Education \& Research, Mahesana, Gujarat, 384012, India
}

\section{ARTICLE INFO}

Received 03 December 2021

Revised 28 January 2022

Available Online 15 February 2022

\section{ACADEMIC EDITOR}

Dr. B.K. Mohanty

\section{*CORRESPONDING AUTHOR}

Dr. Mohammad Asif, Department of Pharmacognosy, Lachoo Memorial College of Science \& Technology Jodhpur, Rajasthan, 342001, India

\begin{abstract}
Background: Efavirenz, a first line anti-retroviral drug has variable bioavailability owing to its limited aqueous solubility. Piperine, a bioavailability enhancer has been often used to enhance the bioavailability of many drugs.

Objective: The present study was aimed to investigate the possibility of improving the bioavailability of efavirenz using piperine.

Methods: Two doses of efavirenz $9.33 \mathrm{mg} / \mathrm{kg}$ and $28 \mathrm{mg} / \mathrm{kg}$ which corresponded to 200 and $600 \mathrm{mg} / \mathrm{kg}$ of human dose were selected. Single oral dose of efavirenz and piperine co administration was given to rabbit and at fixed time interval drug blood concentration was estimated by HPLC. Pharmacokinetic parameters of efavirenz and piperine co administration were determined.

Results: Efavirenz $9.33 \mathrm{mg} / \mathrm{kg}$ co administration with piperine $20.8 \mathrm{mg} / \mathrm{kg}$ increased area under the curve significantly at $p<0.01$ and $C_{\max }$ at $p<0.05$ compared to efavirenz control $(9.33 \mathrm{mg} / \mathrm{kg})$. The relative bioavailability of efavirenz and piperine co-administration was found to be $149.08 \%$, i.e., higher than efavirenz control. $T_{1 / 2}$ of piperine co-administration was also increased significantly at $p<0.05$ compared to efavirenz control. $T_{\max }$ of piperine co-administration was found to be $0.5 \mathrm{~h}$, followed by efavirenz control i.e., $1 \mathrm{~h}$. Co-administration of efavirenz $(28 \mathrm{mg} / \mathrm{kg})$ with piperine $\left(20.8 \mathrm{mg} . \mathrm{kg}\right.$ ) significantly increased AUC and $C_{\max }$ at $p<0.001$ compared to efavirenz control $(28 \mathrm{mg} / \mathrm{kg})$. The relative bioavailability of Piperine coadministration was found to be $158.92 \%$, higher than efavirenz control. There was significant increase in $T_{1 / 2}$ of piperine co-administration at $p<0.01$ compared to efavirenz control. $T_{\max }$ of piperine co-administration and efavirenz were found to be same i.e., $1 \mathrm{~h}$.

Conclusion: Based on the results it can be concluded that piperine coadministration significantly increases the oral exposure of efavirenz. Bioavailability of efavirenz with piperine was found to be higher than efavirenz control.
\end{abstract}

Keywords: Efavirenz; Piperine; HPLC; Area under the curve; $C_{\max } ; T_{\max }$

\section{Introduction}

Bioavailability enhancers concept is derived from traditional system of Ayurveda. There action was first documented by Bose in 1929 where the anti-asthmatic properties of Adhatoda vasika leaves were enhanced by long pepper. These are known to enhance the activity of drug molecules through various ways such as 
potentiating the drug molecules by conformational interaction, making target cells more receptive to drugs, increasing the bioavailability of the drug across the membrane without exerting its own pharmacological activity.

Piperine is the world's first discovered and scientifically validated bioavailability enhancer by an Indian scientist in 1979 at Regional Research Laboratory, Jammu (RRL, now known as Indian Institute of Integrative Medicine.). Piperine is an active principle present in $P$. Longum. Piperine has been reported to increase the bioavailability of several category of drug such as antitubercular, leprosy, antibiotics, NSAIDs. It has been reported to enhance the bioavailability of various drugs ranging from $30 \%$ to $200 \%$. There are several reported mechanisms through which piperine is reported to enhance bioavailability of drugs via inhibition of drug metabolizing enzymes, stimulation of gut amino acid transporters, inhibition of cellular pump required for elimination of drug, inhibiting intestinal glucuronic acid production. It is reported to inhibit UDPglucuronyltransferase and hepatic arylhydrocarbon hydroxylase activities, transferase activity, human pglycoprotein and CYP3A4.Other studies suggests that Piperine also makes receptors more sensitive towards drug, itself act as a receptor, vasodilate the GIT vasculature to enhance absorption. [1]

Efavirenz is a first line antiretroviral drug belonging to category non-nucleoside reverse transcriptase inhibitor. It is one of the preferred constituents of high activity antiretroviral therapy (HAART) for human immunodeficiency virus (HIV) infections. [2]

It mainly acts on HIV-1 reverse transcriptase noncompetitively but lack significant inhibitory effect on HIV-2 reverse transcriptase. Various studies suggest that EFV based regimen with two NRTIs have shown better virologic response compared to triple-NRTIbased regimen or PI based regimen. As per BCS it belongs to Class II drug (high permeability and low solubility). EFV has reported to have $\mathrm{T}_{\max }$ of approximately 3-5 hours. The AUC and $\mathrm{C}_{\max }$ increases proportionally with dose till $1600 \mathrm{mg}$ shedding light that the absorption of efavirenz decreases after this dose. It is more than $99 \%$ protein bound. EFV $400 \mathrm{mg}$ has reported to be $14-34 \%$ excreted in the urine as metabolite and 16-61\% was excreted in faeces as revealed by radiolabelled dose of EFV. EFV is mainly metabolised in liver mainly by CYP3A4 and CYP2B6 to hydroxylated metabolite (inactive) and is reported to have oral bioavailability of $40-45 \%$. [3] Therefore, citing to low bioavailability of efavirenz, the present study was undertaken to evaluate the effect of piperine on pharmacokinetics parameters of efavirenz in rabbit after oral administration of efavirenz at two different doses with or without piperine.

\section{Materials and Methods}

\section{Materials}

Efavirenz was received as gift sample from Al-Chem Pharmaceuticals, Diazepam was purchased from Santham Pharma Pvt. Ltd., Piperine was obtained from Sigma Aldrich (St. Louis, MO, USA). Acetonitrile (HPLC grade) was obtained from S.D Fine Chem Ltd., Water (HPLC grade), Methanol (AR) and potassium EDTA (AR), potassium dihydrogen phosphate (AR) and Tween 80 were obtained from Finar Chemicals Ltd., Ethyl acetate (AR) and hydrochloric acid (AR) were obtained from S.D Fine Chem Ltd., Ethanol (AR) was obtained from Baroda Chemical Industries Ltd.

\section{Experimental animals}

Rabbits (2000-3500 gm), were procured from Central Animal Facility, S.K. Patel College Education and Research, Kherva and housed under standard conditions of temperature $\left(25 \pm 1^{\circ} \mathrm{C}\right)$, relative humidity $(50 \pm 10 \%)$, $12 \mathrm{hr}$ of alternate light and dark cycle. Rabbits were fed with carrot, cauliflower, fresh leaves of vegetables. The care and the use of these animals were in accordance with the guidelines of the CPCSEA (Reg.no. 197/PO/Re/S/2000/CPCSEA).

\section{Calculation of dose}

The dose to be given to experimental rabbits on the basis of surface area was extrapolated as per description of Paget et al. For determination of absolute dose of the experimental rabbit, the absolute dose was multiplied by the factor mentioned as per Paget et al. [4]

Dose to be given to rabbit $=$ Dose of $\operatorname{man}(70 \mathrm{~kg}) \times 0.07$

Dose to be given to rabbit $=$ Dose of rat $(200 \mathrm{gm}) \times 3.9$

Based on above calculation the dose of efavirenz to be administered to rabbit was calculated to be $9.33 \mathrm{mg} / \mathrm{kg}$ (Dose corresponding to $200 \mathrm{mg}$ in humans) and 28 $\mathrm{mg} / \mathrm{kg}$ of rabbit (Dose corresponding to $600 \mathrm{mg}$ in humans); dose of Piperine to be administered was calculated to be $20.8 \mathrm{mg} / \mathrm{kg}$ of rabbit (Dose corresponding to $8 \mathrm{mg}$ in rats); The treatment was 
administered as suspension using Tween 80 as suspending agent.

\section{Experimental design}

The experimental rabbits were divided into six group containing six rabbits in each group. Group I rabbits were administered with efavirenz $(9.33 \mathrm{mg} / \mathrm{kg})$; Group II rabbits were administered with efavirenz + Piperine $(9.33 \mathrm{mg} / \mathrm{kg}+20.8 \mathrm{mg} / \mathrm{kg})$; Group III rabbits were efavirenz (28 mg/kg); Group IV rabbits were administered with efavirenz + Piperine $(28 \mathrm{mg} / \mathrm{kg}+$ $20.8 \mathrm{mg} / \mathrm{kg}$ ). All the group received single oral dose of above drug and blood was collected at $0,0.5,1,2,4,6$, $8,10,24$ and 48 hours respectively from marginal ear vein of rabbit. Blood collected was subjected to plasma separation followed by series of extraction process and sample prepared was finally subjected to estimation of drug by using High Performance Liquid Chromatography.

\section{HPLC assay}

\section{Preparation of calibration curve}

\section{Preparation of standard stock solution}

A stock solution $(50 \mathrm{mg} / \mathrm{ml})$ was prepared by dissolving pure efavirenz in methanol. The working standards of efavirenz in concentrations ranging from 5 to $20000 \mathrm{ng}$ were prepared in rabbit plasma.

\section{Sample preparation of efavirenz}

For each calibration standard, $250 \mu 1$ plasma was taken in $2 \mathrm{ml}$ micro centrifuge tube followed by spiking of 100 ng Diazepam (Internal Standard). Mixture was vortexed for 60 seconds. Standard stock solution of efavirenz, 5, 25, 250, 500, 1000, 2500, 5000, 10000, 15000 and $20000 \mathrm{ng}$ were added separately. Above Plasma sample was extracted by $1000 \mu$ l ethyl acetate, vortexed well for 60 seconds followed by centrifugation at $12000 \mathrm{rpm}$ for 10 minutes. Supernatant organic solution was taken in another $2 \mathrm{ml}$ micro centrifuge tube and evaporated to dryness under gentle nitrogen stream at $37^{\circ} \mathrm{C}$ on water bath. The dried residue was reconstituted in $200 \mu \mathrm{l}$ mobile phase, vortex for 60 seconds followed by centrifugation at $12000 \mathrm{rpm}$ for 10 minutes. Clear solution was subjected to HPLC analysis $[5,6]$

\section{Sample preparation for Group-I-IV}

Healthy rabbits were fasted overnight with free access and were administered single oral dose of respective treatment. Blood samples $(1.5 \mathrm{ml})$ were collected at 0 , $0.5,1,2,3,4,5,6,10,24$ and 48 hours after drug administration in anticoagulant treated micro centrifuge tube and plasma was separated by centrifugation at $12000 \mathrm{rpm}$ for 10 minutes. Above Plasma sample was extracted by $1000 \mu 1$ ethyl acetate, vortexed well for 60 seconds followed by centrifugation at $12000 \mathrm{rpm}$ for 10 minutes. Supernatant organic solution was taken in another $2 \mathrm{ml} \mathrm{micro} \mathrm{centrifuge} \mathrm{tube} \mathrm{and} \mathrm{evaporated} \mathrm{to}$ dryness under gentle nitrogen stream at $37^{\circ} \mathrm{C}$ on water bath. The dried residue was reconstituted in $200 \mu \mathrm{l}$ mobile phase, vortex for 60 seconds followed by centrifugation at $12000 \mathrm{rpm}$ for 10 minutes. Clear solution was subjected to HPLC analysis. $[5,6]$

The HPLC system (Shimadzu Corporation, Kyoto, Japan) consisted of two pumps (LC 20 AD), diode array detector (SPD M20A) and degasser (DGU-20A5). A rheodyne manual injector (7725i) (Rheodyne, Cotati, CA, USA) attached with $20 \mu$ l sample loop was used for loading the sample by $25 \mu \mathrm{l}$ syringe (Hamilton, Bonaduz, Switzerland). Class VP LC workstation was used for data collection and acquisition. The analytical column was a Kromasil C18, 250 x 4.6 mm ID, $5 \mu, 100$ $\AA$ A particle size (Phenomenex, CA, USA) protected by a compatible security guard cartridge system, C18, 4 x 3.0 $\mathrm{mm}$ (Phenomenex, CA, USA). The mobile phase consisted of $10 \mathrm{mM}$ phosphate buffer, $\mathrm{pH} 2.4$ (adjusted with $\mathrm{I} \mathrm{N} \mathrm{HCl})$ and acetonitrile $(55: 45, \mathrm{v} / \mathrm{v})$. Wavelength was set at $247 \mathrm{~nm}$. The chromatogram was run for 25 minutes with flow rate of $2.4 \mathrm{ml} / \mathrm{min}$ at $25^{\circ} \mathrm{C}$. Unknown concentration was derived from linear regression analysis of the calibration curve.

\section{Pharmacokinetic analysis}

Pharmacokinetic parameters in terms one compartment open model were calculated with the area under the plasma concentration-time curves (AUC) were calculated by trapezoidal rule. The maximum plasma concentration $\left(\mathrm{C}_{\max }\right)$ and the time to reach the maximum plasma concentration $\left(\mathrm{T}_{\max }\right)$ were determined by a visual inspection of the experimental data. The terminal phase rate constant $\left(\mathrm{K}_{\mathrm{el}}\right)$ was calculated as the negative of the slope of the log linear terminal portion of the plasma concentration versus time curve using least square regression analysis. The terminal phase half-life $\left(\mathrm{T}_{1 / 2}\right)$ was calculated as $0.693 / \mathrm{K}_{\mathrm{el}}$. The absorption rate constant $\left(\mathrm{K}_{\mathrm{a}}\right)$ was calculated by the residual method. The relative bioavailability of efavirenz after oral administration was calculated as follows: $[7,8]$ 
Citation: Asif M, Patel HP, Patel RK. Oral Bioavailability Enhancement of Efavirenz using Piperine coadministration in Experimental Rabbits. J Pharm Res Sci Technol 2022; 6(1): 156. doi: $\underline{10.31531 / j p r s t .1000156}$

Relative bioavailability $=\left(\frac{\text { AUCcoadmin }}{\text { AUCcontrol }}\right) \times 100$

\section{Statistical analysis}

All the means are presented with their standard deviation. The pharmacokinetic parameters were compared with a one-way ANOVA, followed by a posteriori testing with the use of the Dunnett's correction.

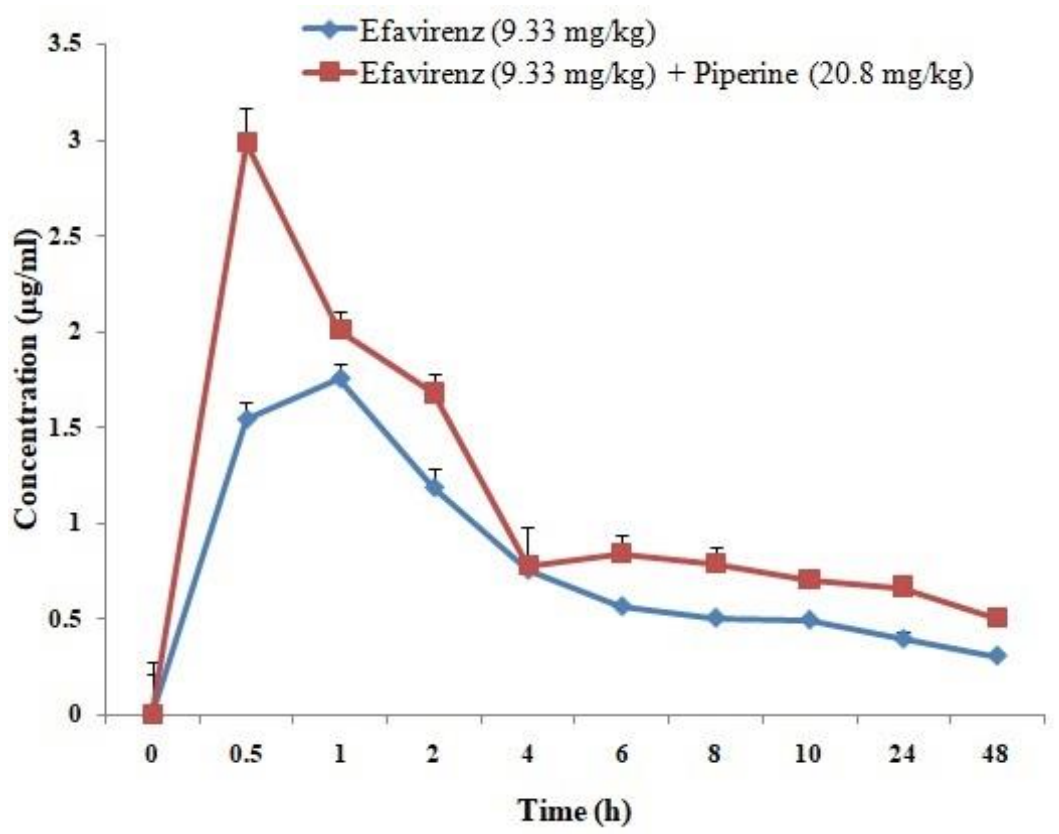

Figure 1: Plasma concentration of efavirenz $(9.33 \mathrm{mg} / \mathrm{kg})$ and efavirenz co-administration with piperine.

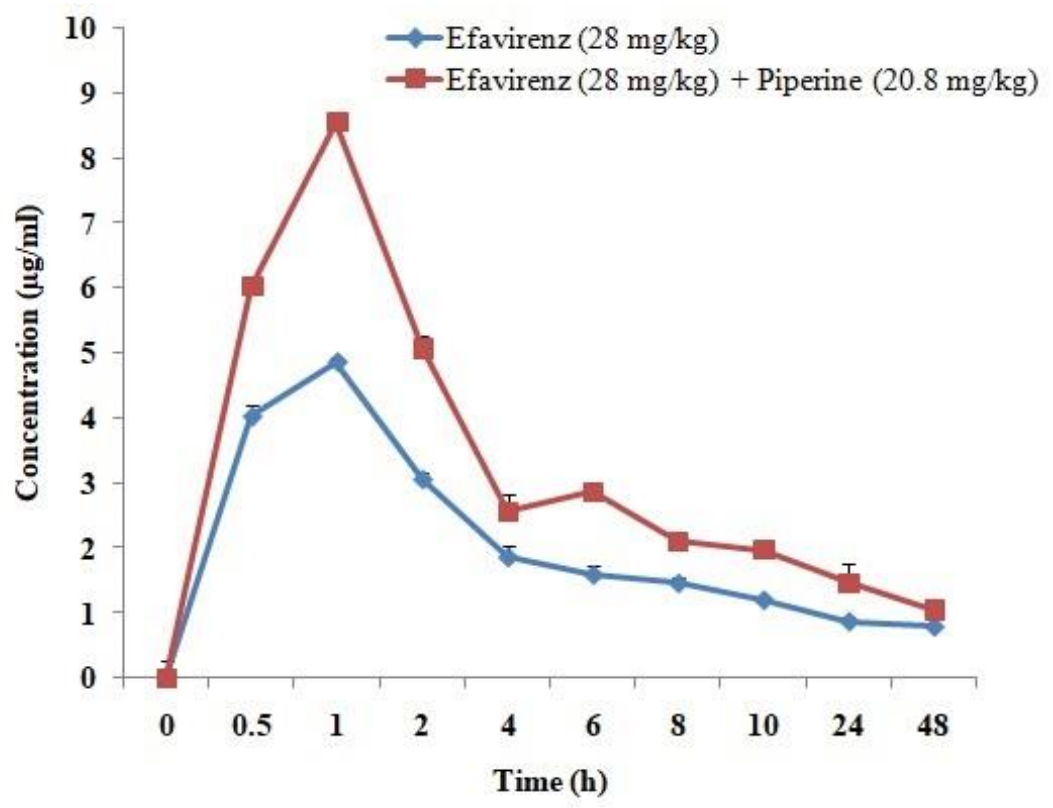

Figure 2: Plasma concentration of efavirenz $(28 \mathrm{mg} / \mathrm{kg})$ and efavirenz co-administration with piperine. 
Citation: Asif M, Patel HP, Patel RK. Oral Bioavailability Enhancement of Efavirenz using Piperine coadministration in Experimental Rabbits. J Pharm Res Sci Technol 2022; 6(1): 156. doi: $\underline{10.31531 / j p r s t .1000156}$

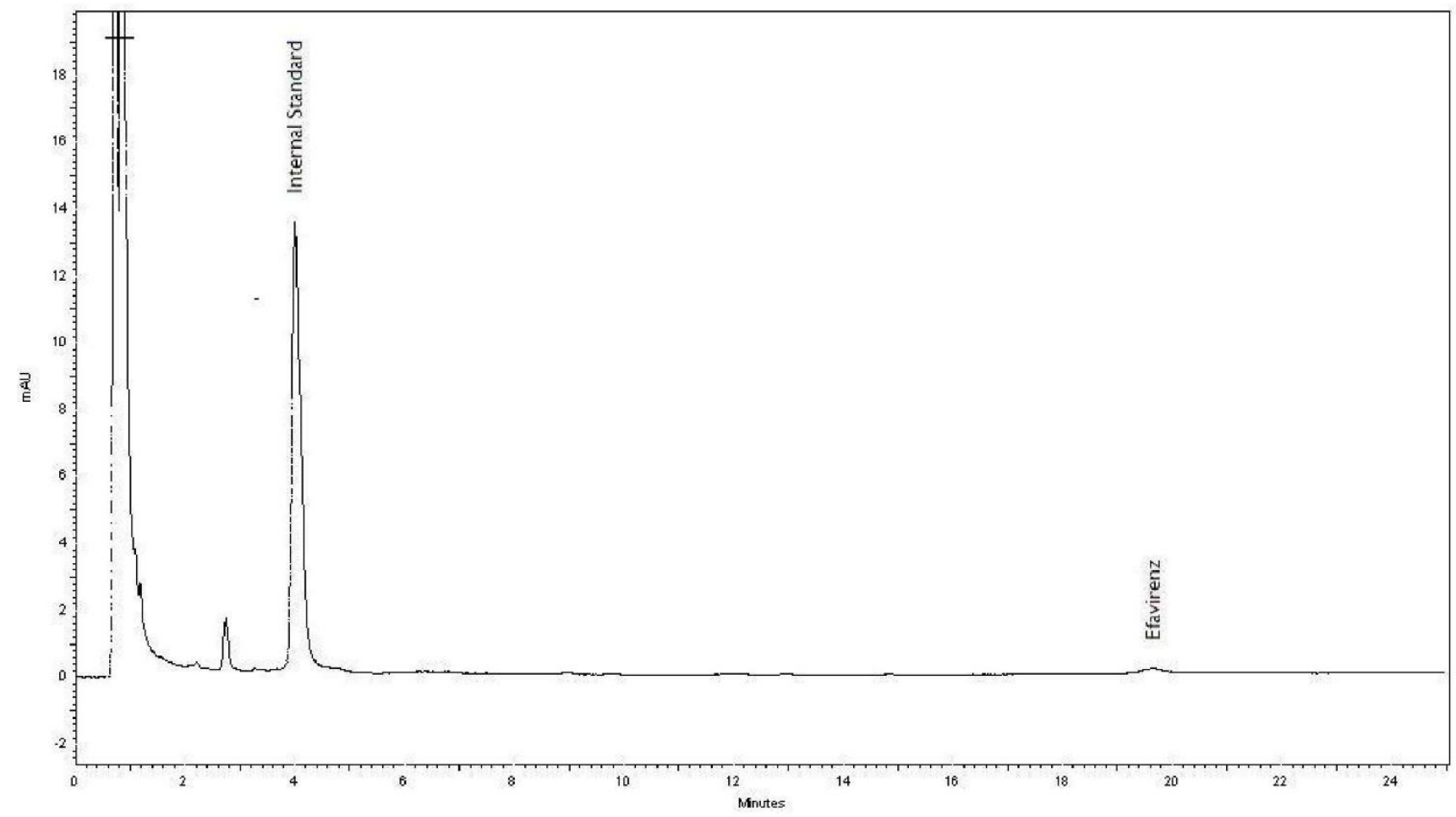

Figure 3: Chromatogram showing efavirenz $9.33 \mathrm{mg} / \mathrm{kg}$ at 1 hour.

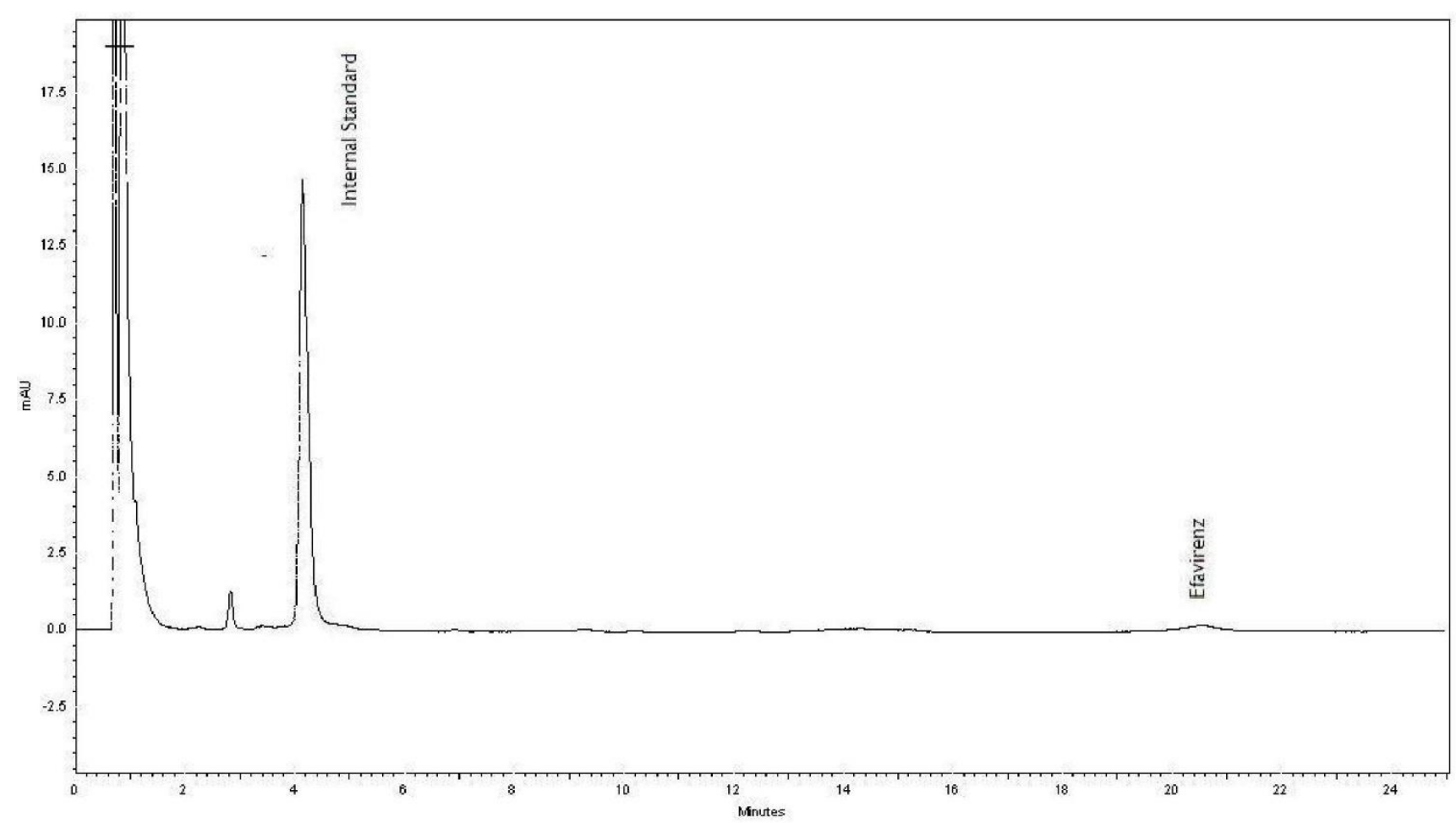

Figure 4: Chromatogram showing efavirenz $9.33 \mathrm{mg} / \mathrm{kg}$ + piperine $20.8 \mathrm{mg} / \mathrm{kg}$ at 1 hour. 
Citation: Asif M, Patel HP, Patel RK. Oral Bioavailability Enhancement of Efavirenz using Piperine coadministration in Experimental Rabbits. J Pharm Res Sci Technol 2022; 6(1): 156. doi: $\underline{10.31531 / j p r s t .1000156}$

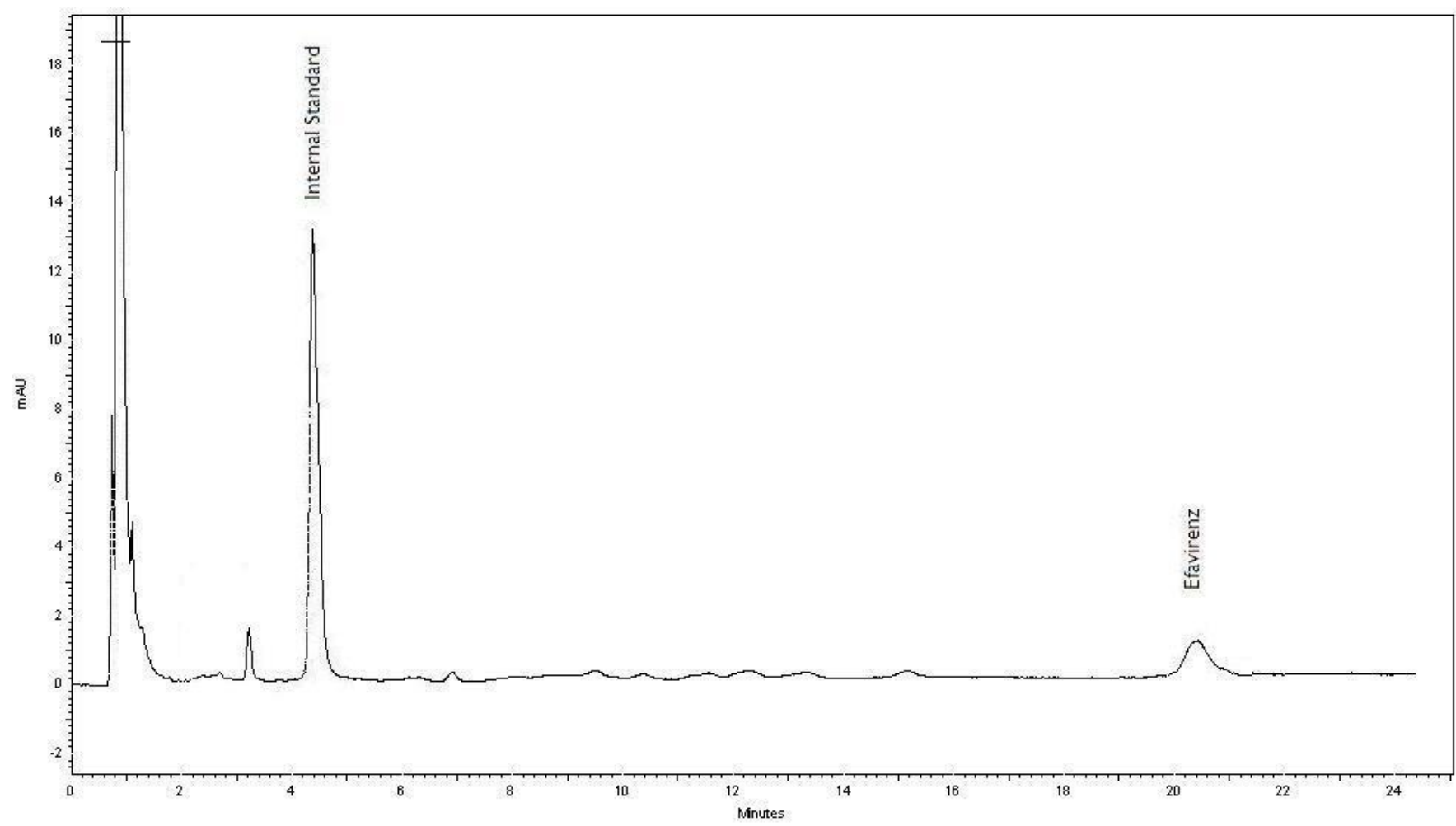

Figure 5: Chromatogram showing efavirenz $28 \mathrm{mg} / \mathrm{kg}$ at 1 hour.

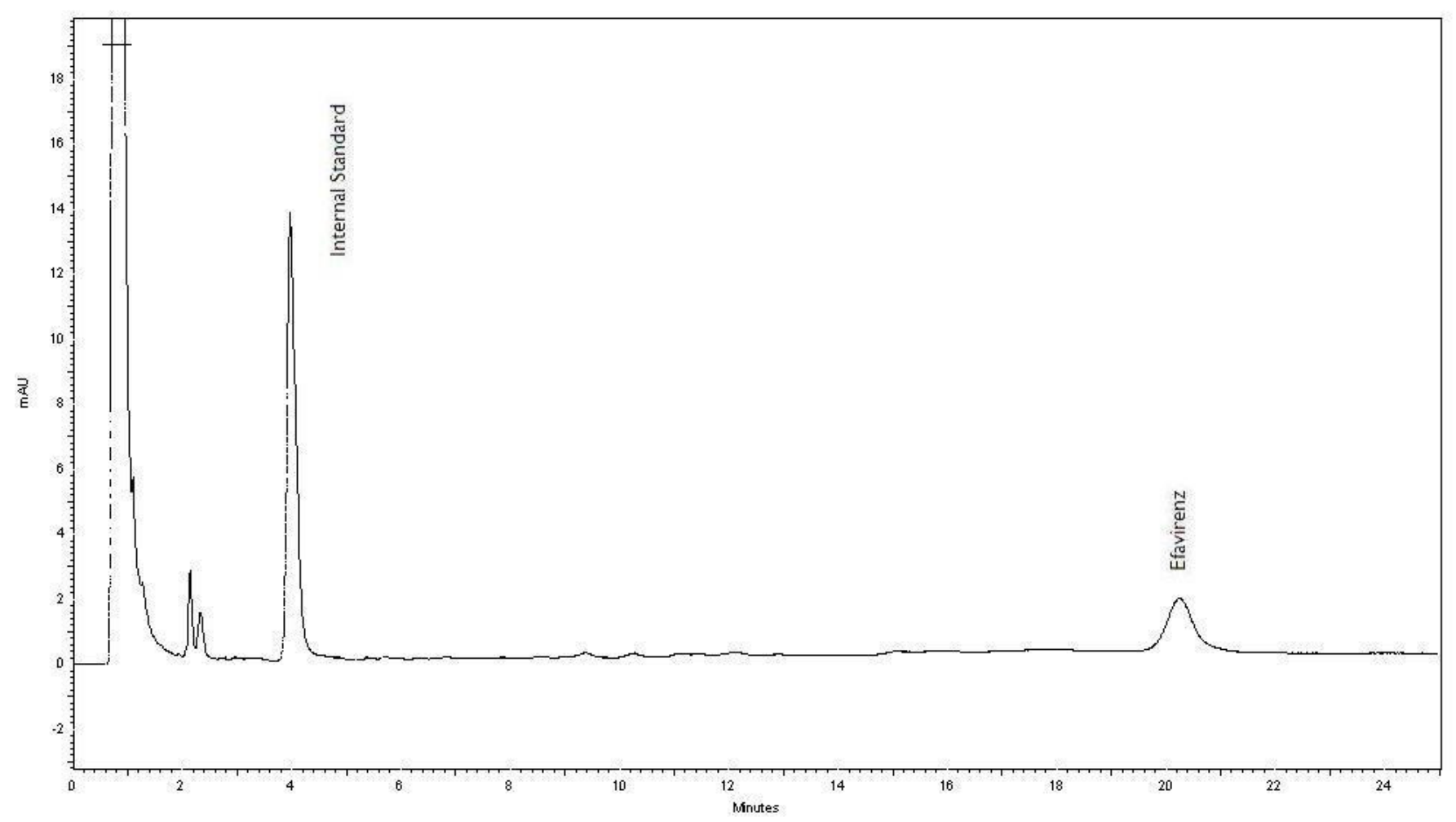

Figure 6: Chromatogram showing efavirenz $28 \mathrm{mg} / \mathrm{kg}+$ piperine $20.8 \mathrm{mg} / \mathrm{kg}$ at 1 hour. 
Citation: Asif M, Patel HP, Patel RK. Oral Bioavailability Enhancement of Efavirenz using Piperine coadministration in Experimental Rabbits. J Pharm Res Sci Technol 2022; 6(1): 156. doi: $\underline{10.31531 / j p r s t .1000156}$

Table 1: AUC of various groups at different concentration and time.

\begin{tabular}{|c|c|c|c|c|c|c|c|c|c|}
\hline \multirow[t]{2}{*}{$\begin{array}{l}\text { S. } \\
\text { No }\end{array}$} & \multirow[t]{2}{*}{$\begin{array}{l}\text { Time } \\
\text { (h) }\end{array}$} & \multicolumn{2}{|c|}{$\begin{array}{c}\text { efavirenz }(9.33 \\
\mathrm{mg} / \mathrm{kg})\end{array}$} & \multicolumn{2}{|c|}{$\begin{array}{c}\text { efavirenz (9.33 } \\
\mathrm{mg} / \mathrm{kg})+ \text { Piperine } \\
(20.8 \mathrm{mg} / \mathrm{kg})\end{array}$} & \multicolumn{2}{|c|}{$\begin{array}{l}\text { efavirenz (28 } \\
\mathrm{mg} / \mathrm{kg})\end{array}$} & \multicolumn{2}{|c|}{$\begin{array}{c}\text { efavirenz }(28)+\text { Piperine } \\
(20.8 \mathrm{mg} / \mathrm{kg})\end{array}$} \\
\hline & & $\begin{array}{l}\text { Conc } \\
(\mu \mathrm{g} / \mathrm{ml})\end{array}$ & $\begin{array}{l}\text { AUC } \\
\pm \text { SD }\end{array}$ & $\begin{array}{c}\text { Conc } \\
(\mu \mathrm{g} / \mathrm{ml})\end{array}$ & AUC \pm SD & $\begin{array}{l}\text { Conc } \\
(\mu \mathrm{g} / \mathrm{ml})\end{array}$ & $\mathbf{A U C} \pm \mathrm{SD}$ & $\begin{array}{c}\text { Conc } \\
(\mu \mathrm{g} / \mathrm{ml})\end{array}$ & $\mathbf{A U C} \pm \mathbf{S D}$ \\
\hline 1 & 0 & 0 & 0 & 0 & 0 & 0 & 0 & 0 & 0 \\
\hline 2 & 0.5 & 1.545 & $\begin{array}{l}0.38625 \\
\pm 0.6761\end{array}$ & $\begin{array}{c}2.98679 \\
9\end{array}$ & $\begin{array}{r}0.7466997 \\
5 \pm 0.5106\end{array}$ & 4.03 & $\begin{array}{l}1.0075 \pm 0 . \\
3872\end{array}$ & 6.036 & $\begin{array}{l}1.509 \pm 0.668 \\
9\end{array}$ \\
\hline 3 & 1 & $\begin{array}{c}1.75838 \\
7\end{array}$ & $\begin{array}{c}0.82584 \\
675 \pm 0.2 \\
121\end{array}$ & $\begin{array}{c}2.00876 \\
4\end{array}$ & $\begin{array}{c}1.2488907 \\
5 \pm 0.4331\end{array}$ & 4.87 & $\begin{array}{l}2.225 \pm 0.3 \\
972\end{array}$ & 8.56 & $\begin{array}{c}3.649 \pm 0.342 \\
7\end{array}$ \\
\hline 4 & 2 & $\begin{array}{c}1.18686 \\
3\end{array}$ & $\begin{array}{c}1.47262 \\
5 \pm 0.193 \\
4\end{array}$ & 1.67878 & $\begin{array}{l}1.843772 \pm \\
0.2472\end{array}$ & 3.06 & $\begin{array}{l}3.965 \pm 0.1 \\
786\end{array}$ & 5.07 & $\begin{array}{c}6.815 \pm 0.108 \\
7\end{array}$ \\
\hline 5 & 4 & $\begin{array}{c}0.75460 \\
78\end{array}$ & $\begin{array}{c}1.94147 \\
08 \pm 0.24 \\
89\end{array}$ & $\begin{array}{l}0.77806 \\
9\end{array}$ & $\begin{array}{l}2.456849 \pm \\
0.2366\end{array}$ & 1.86 & $\begin{array}{c}4.92 \pm 0.23 \\
81\end{array}$ & 2.565 & $\begin{array}{c}7.635 \pm 0.494 \\
1\end{array}$ \\
\hline 6 & 6 & $\begin{array}{c}0.56536 \\
58\end{array}$ & $\begin{array}{c}1.31997 \\
36 \pm 0.12 \\
26\end{array}$ & $\begin{array}{c}0.83842 \\
86\end{array}$ & $\begin{array}{c}1.6164976 \\
\pm 0.4854\end{array}$ & 1.59 & $\begin{array}{c}3.45 \pm 0.42 \\
31\end{array}$ & 2.86 & $\begin{array}{l}5.425 \pm 0.681 \\
2\end{array}$ \\
\hline 7 & 8 & $\begin{array}{c}0.50452 \\
48\end{array}$ & $\begin{array}{c}1.06989 \\
06 \pm 0.00 \\
34\end{array}$ & $\begin{array}{c}0.78963 \\
46\end{array}$ & $\begin{array}{c}1.6280632 \\
\pm 0.2578\end{array}$ & 1.46 & $\begin{array}{c}3.05 \pm 0.32 \\
35\end{array}$ & 2.1 & $4.96 \pm 0.0403$ \\
\hline 8 & 10 & $\begin{array}{c}0.49420 \\
54\end{array}$ & $\begin{array}{c}0.99873 \\
02 \pm 0.03 \\
51\end{array}$ & $\begin{array}{c}0.70392 \\
15\end{array}$ & $\begin{array}{c}1.4935561 \\
\pm 0.2196\end{array}$ & 1.2 & $\begin{array}{c}2.66 \pm 0.19 \\
36\end{array}$ & 1.97 & $4.07 \pm 0.1550$ \\
\hline 9 & 24 & $\begin{array}{c}0.39495 \\
35\end{array}$ & $\begin{array}{c}6.22411 \\
23 \pm 0.01 \\
36\end{array}$ & $\begin{array}{c}0.66541 \\
5\end{array}$ & $\begin{array}{c}9.5853555 \\
\pm 0.1100\end{array}$ & 0.87 & $\begin{array}{c}14.49 \pm 0.1 \\
100\end{array}$ & 1.46 & $\begin{array}{c}24.01 \pm 0.136 \\
1\end{array}$ \\
\hline 10 & 48 & $\begin{array}{c}0.30662 \\
33\end{array}$ & $\begin{array}{c}8.41892 \\
16 \pm 0.10 \\
77\end{array}$ & $\begin{array}{c}0.50656 \\
5\end{array}$ & $\begin{array}{l}14.06376 \pm \\
0.1629\end{array}$ & 0.79 & $\begin{array}{l}19.92 \pm 0.1 \\
652\end{array}$ & 1.05 & $30.12 \pm 0.7210$ \\
\hline
\end{tabular}

\section{Results}

The mean plasma concentration - time profile of efavirenz at dose 9.33 and $28 \mathrm{mg} / \mathrm{kg}$ with and without piperine were characterized in rabbit and illustrated in Figures 1 and 2. Area under the curve (AUC) at different concentration and time has been detailed in table 1. HPLC analysis from each group at 1 hour is depicted in Figures 3-6. The pharmacokinetic parameters of efavirenz $(9.33 \mathrm{mg} / \mathrm{kg}$ and $28 \mathrm{mg} / \mathrm{kg})$, piperine co-administration have been detailed in Table 2.
Co-administration of efavirenz $(9.33 \mathrm{mg} / \mathrm{kg})$ with piperine significantly increased area under the curve at $\mathrm{p}<0.01$, compared to efavirenz control. Similarly, $\mathrm{C}_{\max }$ with piperine co-administration increased significantly at $\mathrm{p}<0.05$ compared to efavirenz control $(9.33 \mathrm{mg} / \mathrm{kg})$. The relative bioavailability of Piperine coadministration was found to be $149.08 \%$, higher than efavirenz control. $T_{1 / 2}$ of piperine co-administration was also increased significantly at $\mathrm{p}<0.05$ compared to efavirenz control. $\mathrm{T}_{\max }$ of piperine co-administration was found to be $0.5 \mathrm{~h}$, followed by efavirenz control i.e., $1 \mathrm{~h}$. 
Citation: Asif M, Patel HP, Patel RK. Oral Bioavailability Enhancement of Efavirenz using Piperine coadministration in Experimental Rabbits. J Pharm Res Sci Technol 2022; 6(1): 156. doi: 10.31531/jprst.1000156

Table 2: Pharmacokinetic parameter of various groups.

\begin{tabular}{|c|c|c|c|c|}
\hline Parameters & $\begin{array}{c}\text { efavirenz } \\
\text { control } \\
(9.33 \mathrm{mg} / \mathrm{kg})\end{array}$ & $\begin{array}{l}\text { Piperine } \\
\text { co-admin }\end{array}$ & $\begin{array}{l}\text { efavirenz control } \\
(28 \mathrm{mg} / \mathrm{kg})\end{array}$ & Piperine co-admin \\
\hline $\mathbf{K}_{\mathbf{a}}$ & $0.3132 \pm 0.073$ & $0.0437 \pm 0.009 * *$ & $0.2625 \pm 0.048$ & $0.1335 \pm 0.042^{* *}$ \\
\hline$K_{\text {el }}$ & $0.3316 \pm 0.083$ & $0.2924 \pm 0.067 * *$ & $0.5135 \pm 0.099$ & $0.3638 \pm 0.079 * *$ \\
\hline $\operatorname{AUC}_{0-48}(\mu \mathrm{g} / \mathrm{ml})$ & $22.65 \pm 4.65$ & $34.68 \pm 5.29 * *$ & $55.68 \pm 7.69$ & $88.19 \pm 10.38^{* * *}$ \\
\hline $\mathrm{C}_{\max }(\mu \mathrm{g} / \mathrm{ml})$ & $1.75 \pm 0.45$ & $2.98 \pm 0.53^{*}$ & $4.86 \pm 0.81$ & $8.56 \pm 1.39 * * *$ \\
\hline $\mathbf{T}_{\max }(\mathbf{h})$ & 1 & 0.5 & 1 & 1 \\
\hline $\mathbf{T}_{1 / 2}(\mathrm{~h})$ & $2.089 \pm 0.55$ & $2.369 \pm 0.69 *$ & $1.349 \pm 0.38$ & $1.904 \pm 0.42 * *$ \\
\hline R.B\% & 100 & 149.058 & 100 & 158.95 \\
\hline \multicolumn{5}{|c|}{$\begin{array}{l}\text { Mean } \pm \text { S.D. }(n=6), K_{\mathrm{a}} \text { : Absorption rate constant, } \mathrm{K}_{\mathrm{el}} \text { : Elimination rate constant, AUC } \mathrm{C}_{0-48} \text { Area under the plasma } \\
\text { concentration-time curve from } 0 \text { to } 48 \text { hours, } \mathrm{C}_{\max } \text { Peak concentration, } \mathrm{T}_{\max } \text { : Time to reach peak concentration, } \\
\mathrm{t}_{1 / 2}: \text { Terminal half-life, RB: Relative bioavailability AUC rate compared to AUC control. } * \mathrm{p}<0.05 \text { compared to } \\
\text { control, } * * \mathrm{p}<0.01 \text { compared to control, } * * * \mathrm{p}<0.001 \text { compared to control \#=Not significant compared to control. }\end{array}$} \\
\hline
\end{tabular}

Co-administration of efavirenz $(28 \mathrm{mg} / \mathrm{kg})$ with piperine significantly increased AUC at $\mathrm{p}<0.001 . \mathrm{C}_{\max }$ with co-administration of piperine increased significantly at $\mathrm{p}<0.001$ compared to efavirenz control $(28 \mathrm{mg} / \mathrm{kg})$. The relative bioavailability of Piperine coadministration was found to be $158.92 \%$, higher than efavirenz control. There was significant increase in $\mathrm{T}_{1 / 2}$ of piperine co-administration at $\mathrm{p}<0.01$ compared to efavirenz control. $\mathrm{T}_{\max }$ of piperine co-administration and efavirenz were found to be same i.e., $1 \mathrm{~h}$.

\section{Discussion}

The present study evaluated the effect of piperine on an anti-retroviral drug efavirenz which is prominently used in its class. Most of the currently used anti-retroviral drugs have a narrow therapeutic index. [9] Hence it is prudent to monitor the plasma drug levels to ensure that it is well within the therapeutic range. [10] Apart from studying pharmacokinetics it will also help to ensure that a minimum therapeutic concentration is achieved at the initiation of therapy and the maximum recommended therapeutic concentration is not exceeded during the dose escalation phase. [11] The enhancement of systematic availability of efavirenz by piperine assumes the additional significance to enhance the bioavailability of co-administered drugs, as reported in this and previous studies, can be considered from a different perspective. The results of this study demonstrated that efavirenz when co-administered with piperine significantly increased the blood drug concentration. The enhanced absorption could be due to retardation of CYP3A4 by which efavirenz is metabolized and an alteration of membrane dynamics which aid in efficient permeability through membranes. The maximum concentrations reached in both the dose groups were significantly increased when piperine coadministered along with efavirenz, suggesting that the extent of absorption was also increased. It been postulated that piperine causes inhibition of the hepatic Cytochrome P450 enzyme system. This study may provide a therapeutic benefit whereby it enhances oral exposure and lowers the dose administered. Since the present study raised the awareness about the potential drug interactions by concomitant use of piperine, principal constituent of piper nigrum and piper longum [12], with efavirenz, the clinical significance of this finding needs to be further evaluated in the clinical studies.

\section{Conclusion}

Efavirenz $(9.33 \mathrm{mg} / \mathrm{kg}$ and $28 \quad \mathrm{mg} / \mathrm{kg})$ when administered along with piperine $(20.8 \mathrm{mg} / \mathrm{kg})$ significantly enhanced the oral exposure of drug in rabbits. Concomitant use of piperine or piperinecontaining dietary supplements with efavirenz may require close monitoring for potential drug interaction. Further, oral efavirenz preparations along with bioenhancer Piperine could be developed to ensure the less 
adverse complications and lessening cost of medication with improved patient compliance.

\section{Consent for Publication}

Not applicable.

\section{Funding}

None.

\section{Conflict of Interest}

The author declares no conflict of interest, financial or otherwise.

\section{Acknowledgements}

Declared none.

\section{References}

1. Kesarwani K, Gupta R, Mukerjee A. Bioavailability enhancers of herbal origin: an overview. Asian. Pac. J. Trop. Biomed 2013; 3(4):253-266

2. Gaur PK, Mishra S, Bajpai M, Mishra A. Enhanced oral bioavailability of Efavirenz by solid lipid nanoparticles: In vitro drug release and pharmacokinetics studies. Biomed. Res. Int 2014; 2014: 363404.

3. Usach I, Melis, V, Peris, JE. Non-nucleoside reverse transcriptase inhibitors: a review on pharmacokinetics, pharmacodynamics, safety and tolerability. J. Int. AIDS. Soc 2013; 16(1):1-14.

4. Paget GE, Barnes JM. Toxicity tests. In: Evaluation of Drug Activities: Pharmacometrics; Lawrence, D. R.; Bacharach, A. L., Eds.; Academic Press: London, 1964, pp. 140-161.
5. Hiwale AR, Dhuley JN, Naik SR. Effect of coadministration of piperine on pharmacokinetics of beta-lactam antibiotics in rats. Indian. J. Exp. Biol. 2002; 40(3): 277-281.

6. Ramachandran G, Kumar AKH, Swaminathan S, Venkatesan P, Kumaraswami V, Greenblatt DJ. Simple and rapid liquid chromatography method for determination of efavirenz in plasma. J. Chromatogr. B 2006; 835(1-2): 131-135.

7. Choi JS, Shin SC. Enhanced paclitaxel bioavailability after oral coadministration of paclitaxel prodrug with naringin to rats. Int. J. Pharm. 2005; 292(1-2): 149-156.

8. Choi JS, Han HK. Enhanced oral exposure of diltiazem by the concomitant use of naringin in rats. Int J Pharm. 2005; 305(1-2): 122-128

9. Soldin OP, Elin RJ, Soldin SJ. Therapeutic drug monitoring in human immunodeficiency virus/acquired immunodeficiency syndrome. Quo vadis? Arch. Pathol. Lab. Med. 2003; 127(1): 102105.

10. Kang JS, Lee MH. Overview of therapeutic drug monitoring. Korean. J. Intern. Med. 2009;24(1): 110.

11. Tamargo J, Le Heuzey JY, Mabo P. Narrow therapeutic index drugs: a clinical pharmacological consideration to flecainide. Eur. J. Clin. Pharmacol. 2015;71(5):549-567.

12. Mhaske DB, Sreedharan S, Mahadik KR. Role of Piperine as an Effective Bioenhancer in Drug Absorption. Role of Piperine as an Effective Bioenhancer in Drug Absorption. Pharm. Anal. Acta. 2018; 9: 7.

Copyright: (02022 Asif M, et al. This article is distributed under the terms of the Creative Commons Attribution 4.0 International License (http://creativecommons.org/licenses/by/4.0/), which permits unrestricted use, distribution, and reproduction in any medium, provided you give appropriate credit to the original author(s) and the source, provide a link to the Creative Commons license, and indicate if changes were made. 